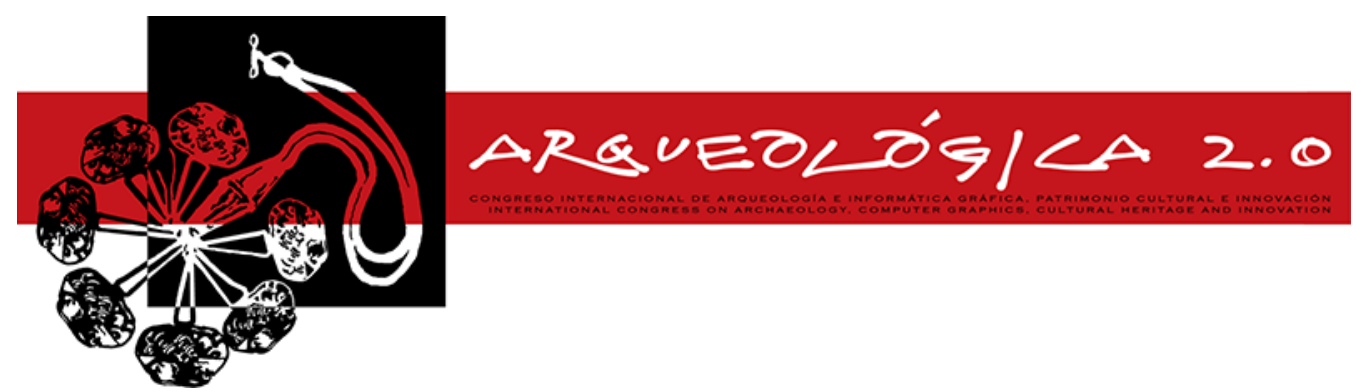

Proceedings of the $8^{\text {th }}$ International Congress

on Archaeology,

Computer Graphics,

Cultural Heritage and Innovation

'AROUEOLÓGICA 2.0'

in Valencia (Spain),

Sept. $5-7,2016$

DOI: http://dx.doi.org/10.4995/arqueologica8.2016.3002

Received: 04/03/2016

Accepted: 05/04/2016

\title{
3D DIGITAL TECHNOLOGIES TO RECORD EXCAVATION DATA: THE CASE OF THE CATACOMBS OF ST. LUCY (SIRACUSA, SICILY)
}

\section{TECNOLOGÍA DIGITAL 3-D PARA REGISTRAR DATOS DE EXCAVACIÓN: EL CASO DE LAS CATACUMBAS DE SANTA LUCÍA (SIRACUSA, ITALIA)}

\author{
Ilenia Gradante ${ }^{a}$, Mariarita Sgarlata ${ }^{a}$, Davide Tanasi ${ }^{\mathrm{b},{ }^{,}}$ \\ ${ }^{a}$ Römisches Institut der Görres-Gesellschaft, Campo Santo Teutonico, 00120 Città del Vaticano. ileniag@hotmail.com \\ b Università di Catania, Dipartimento di Scienze Umanistiche, Piazza Dante 32, 95124 Catania, Italia. m.sgarlata@unict.it \\ c University of South Florida, Center for Virtualization and Applied Spatial Technologies (CVAST) \& Department of History, 4202 E \\ Fowler Ave, Tampa, FL 33620, USA. dtanasi@usf.edu
}

\begin{abstract}
:
Between 2013 and 2015, Arcadia University in partnership with the Pontifical Commission for Sacred Archaeology and the University of Catania undertook new excavation campaigns in the Catacombs of St. Lucy at Siracusa. The research focuses on some very problematic parts of Region C of the complex, including Oratory C, the so-called Pagan Shrine and Crypt VI. These areas document most effectively the long life of this Christian hypogeum, which incorporated previous structures and artefacts related to the Greek period and continued to be used until the Middle Ages. During the excavation an array of 3D digital techniques (3D scanning, 3d Modelling, Image-based 3D modelling) was used for the daily recording of the archaeological units, but also to create high-resolution virtual replicas of certain districts of the catacombs. Furthermore, the same techniques were applied to support the study of certain classes of materials, such as frescoes and marble architectural elements that could otherwise only be studied in the dark environment of the catacombs, making the visual analysis of such complex artifacts difficult and sometimes misleading, not to mention that the frequent use of strong sources of light for study can also endanger them. The virtual archaeology research undertaken at the Catacombs of St. Lucy represents the first systematic application of 3D digital technologies to the study of such a special archaeological context in Sicily.
\end{abstract}

Key words: Christian catacombs, Sicily, virtual archaeology, 3D scanning, 3D modelling, Image-based 3D modelling, Open source

\section{Resumen:}

Entre los años 2013 hasta 2015, La Universidad de Arcadia conjunto con la Comisión Pontifical para Arqueología Sagrada y la Universidad de Catania se comprometieron a hacer nuevas excavaciones en las catacumbas de Santa Lucia en Siracusa. La investigación se enfoca en unas de las partes mas problemáticas de la región C del complejo, como la oratoria C, los dos así llamados santuarios paganos y la cripta VI. Estas áreas documentan la larga historia del hipogeo cristiano mejor que otras lo cual incorporó previas estructuras y artefactos relacionados con el periodo griego y siguió ser usado hasta el Medioevo. Durante la excavación, un despliegue de técnicos digitales en 3D (el escaneo 3D, el modelado en 3D hecho a mano, el modelado 3D basado en la imagen) fueron usados para la registro diario de las unidades arquitectónicas, pero también para crear replicas virtuales de alta resolución de ciertas regiones de las catacumbas. Además, las mismas técnicas fueron aplicadas para apoyar el estudio de ciertas clases de materiales, como frescos y elementos arquitectónicos de mármol, los cuales sólo se puede estudiar en la oscuridad de las catacumbas que lo hace difícil y a veces engaña el análisis visual de esos objetos tan complejos, por no hablar del uso frecuente de fuentes fuertes de luz para investigar los objetos que también puede ponerlos en peligro. La investigación arqueológica virtual que aconteció en las catacumbas de Santa Lucia representa la primera aplicación sistémica de tecnologías digitales en 3D para la investigación de un contexto arqueológico tan peculiar en Sicilia.

Palabras clave: catacumbas cristianas, Sicilia, arqueología virtual, escaneo 3D, modelado 3D, modelado 3D basado en imagen, código abierto

*Corresponding Author: Davide Tanasi, dtanasi@usf.edu 


\section{Introduction}

The growing popularity of virtual archaeology has substantially changed the perspective of archaeologists towards the object of their study, conditioning their field strategies and directing their research perspectives (Stanco and Tanasi 2011; Hugget 2013; Economou 2015). The application of certain 3D imaging solutions turned out to be extremely helpful for the analysis of peculiar archaeological contexts, such as the Christian catacombs, characterized by a multi-faceted architectural history and by dark restricted environments (Zimmermann 2008).

In the framework of the excavation project undertaken by the Pontifical Commission of Sacred Archaeology, Arcadia University and the University of Catania at the Catacombs of St. Lucy at Siracusa (Fig. 1), one of the most important Late Roman cultural complexes of Sicily (Sgarlata and Salvo 2006; Sgarlata 2007), an array of different 3D Digital Imaging techniques were used to record excavation data. The scientific exercises were carried out by American undergraduate students previously trained in the use of open-source software for data-processing and low-cost 3D scanning devices such as Microsoft Kinect and Occipital Structure. In some cases, triangulation 3D scanning and image-based 3D modelling were also used. The combination of archaeological excavation with the phase of digital recording represents a very important educative experiment in the field of digital archaeology. With regards to the areas of intervention, as well as the areas of Oratory C and Crypt $\mathrm{VI}$, a successful research exercise was carried out in the 'Pagan Shrine'.

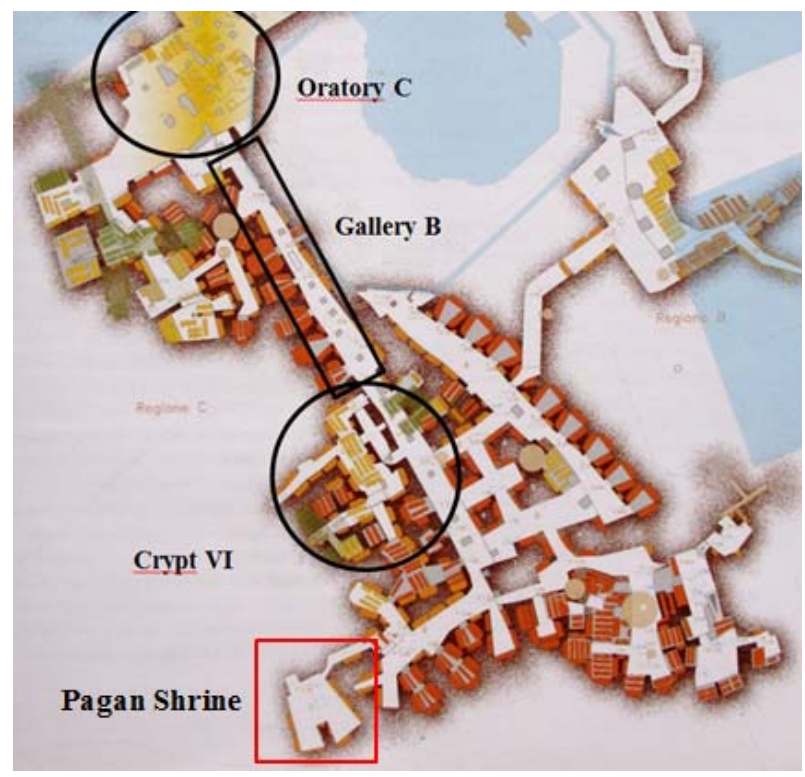

Figure 1: Plan of Region C of the Catacombs of St. Lucy, indicating the areas where 3D digital technologies for data recording were applied.

The enormous amount of digital data acquired in the different tasks was processed using the workstations of the Arcadia Virtual Archaeology Laboratory at Siracusa and the open-source software Meshlab (Cignoni et al. 2008) for the mesh processing, and Blender (Delli Ponti et al. 2011) for the 3D modelling integration.

\section{Oratory C}

Region $\mathrm{C}$ of the catacombs, certainly dated to postConstantinian times (4th century $A D$ ) and used for funerary purposes until the end of the 5th century AD, offers significant evidence for the Medieval phase of use. After the cemetery falls into disuse for burial, the catacombs undergo a series of architectural and monumental transformations that turn it into a true place of martyrial worship: in particular, the so-called "Oratory C" (Fig. 2). The walls are entirely covered with frescoes which in places overlap to form four layers on top of each other (called palimpsests), ranging in chronology from Byzantine times to the Norman period. The frescocycle consists of panels painted with figures of saints, two of which are clearly distinguished by the presence of captions in Latin. The most significant palimpsest is on the eastern wall of Room I, traditionally known as the "Fresco of the Little Commissioner", due to the figure of an old man with outstretched hands as if in prayer to the great saints to his right, on the left corner of the panel (Fig. 3). The characteristics of the oratory and in particular of the Fresco of the Little Commissioner are the writing and graphic testimonials left by pilgrims who visited the hypogeum, attracted to the venerated resting place of the body of St. Lucy nearby up until the 11th century.

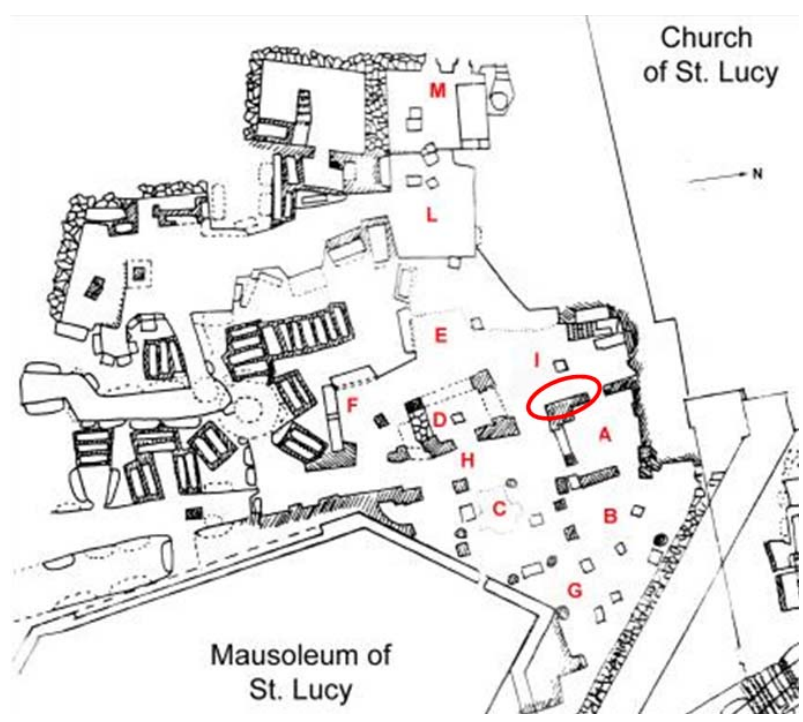

Figure 2: Plan of Oratory $C$ with indication of the location of the Fresco of the Little Commissioner.
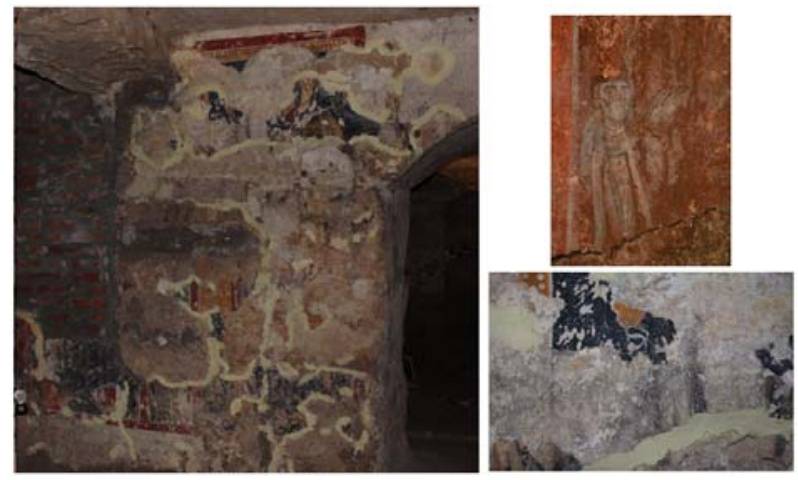

Figure 3: Eastern wall of Room I (Oratory C, Region C): Fresco of the Little Commissioner. 


\subsection{The 3D laser scanning of the Fresco of the Little Commissioner}

Considering the total lack of monitoring for the natural decay of the fresco and the extreme environmental conditions of the catacombs, it was decided to produce a virtual replica of the fresco using 3D laser scanning. The virtual model would provide a unalterable 3D image of the artefact, and properly manipulated, would improve the readability of the writings.

The 3D laser scanning (Fig. 4) was carried out with a NextEngine triangulation 3D scanner in macro setting. Due to the high level of details of the artefact - different strata of paint and multiple layers of graffiti -, it was decided to rely on macro scans, acquiring sections of the surface of $5.1 \times 3.8 \mathrm{~cm}$ at a time, for a total of 75 scans organized on vertical strips. Coded targets were applied on the fresco in order to create a reference grid to facilitate the alignment of the scanned portions.
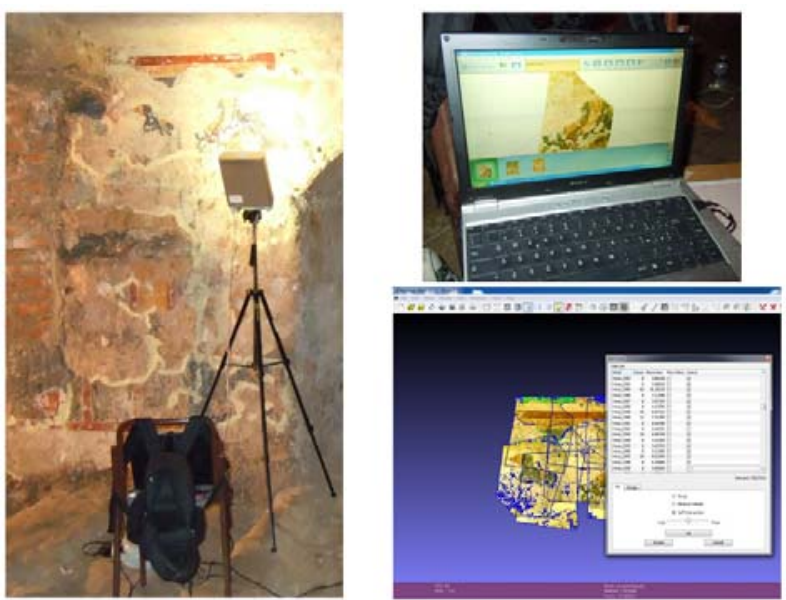

Figure 4: Acquisition via triangulation laser scanner of the fresco and initial data processing.

During data processing, the open-source software Meshlab was used for alignment and for filling gaps and removing noise and the coded targets. The 3D model resulting from the alignment of three main portions, showed circa $46 \mathrm{M}$ vertices and $95 \mathrm{M}$ faces, and the portions of it bearing graffiti turned out to be significantly more readable than they were on the digital pictures (Figs. 5, 6).

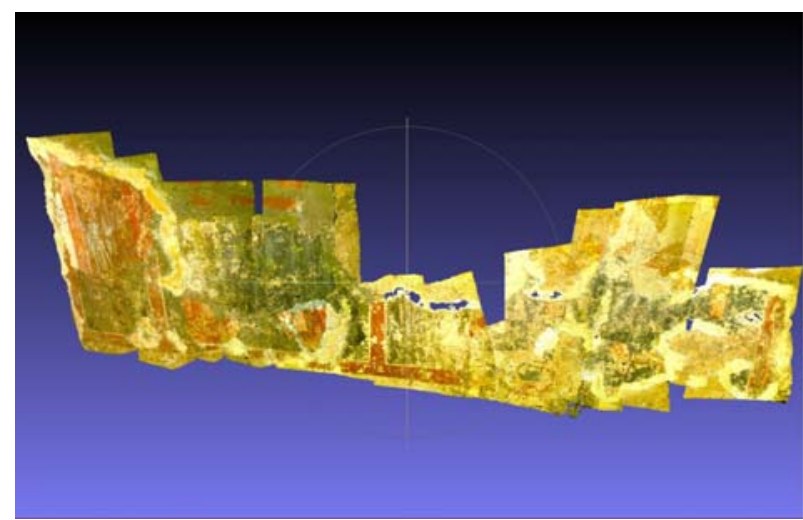

Figura 5: High quality 3D model of the lower part of the fresco.

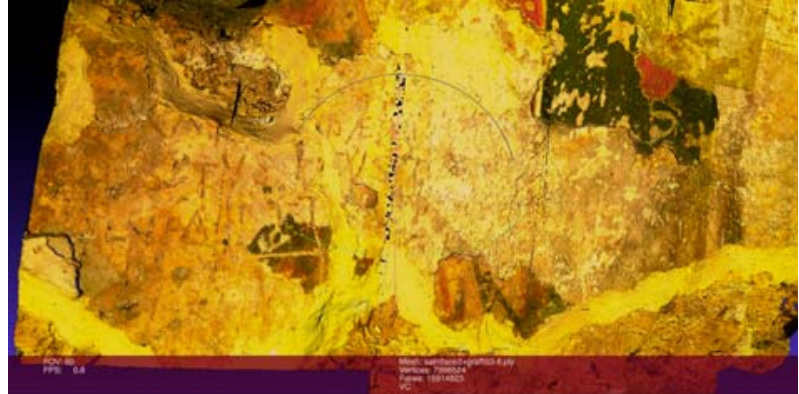

Figura 6: High quality 3D model of the lower part of the fresco, details of the graffiti.

\subsection{The 3D digital documentation of the trench in Room A}

The restricted space provided by Room A represented the best environment in which to use 3D scanning to document the progress in the excavation of the formae opened on the floor. In particular, in the case of tombs $2043,2044,2045$, showing a complex stratigraphy characterized by later phases of reuse, this method turned out to be particularly useful.

In order to not slow down the excavation work, the 3D scans were carried out using an infrared light structured portable scanner (Occipital Structure), providing high detail models in a short time (Fig. 7). Simultaneously the scanner was used to produce the 3D model of the four internal walls of Room $A$, characterized by several different types of masonry and old restoration interventions.

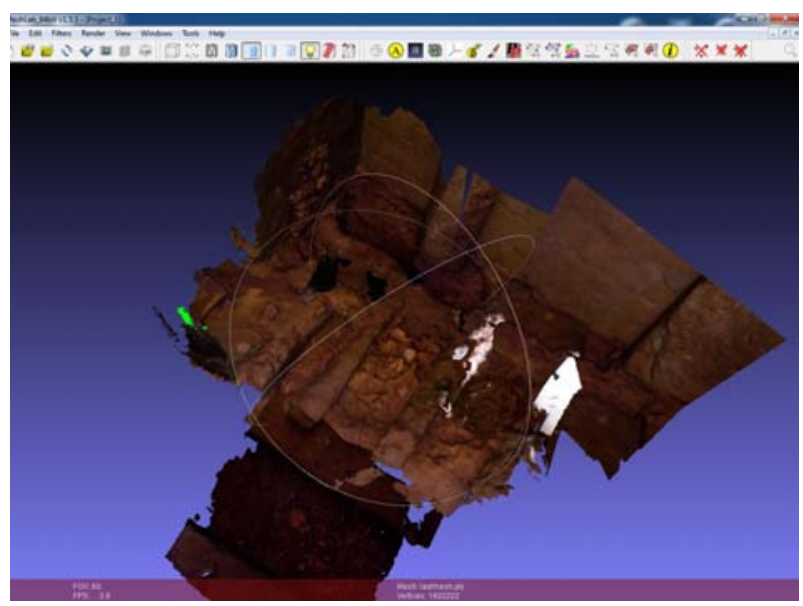

Figure 7: 3D model of Room A of Oratory $C$ acquired after the exploration of tombs 2045, 2046 and 2047.

\subsection{The 3D digital documentation of tomb 2174 in Room F}

The excavation of tomb 2174 , in the north-eastern corner of Room $\mathrm{F}$, required particular care in the data recording. The presence of multiple burials and the possibility that the tomb had been ransacked but still held several findings, especially bronze coins, suggested that we employ the NextEngine triangulation 3D laser scanner in macro setting (Fig. 8). Five scans for each of the four stratigraphic units identified were carried out for a total of twenty scans organized in vertical strips. During data processing the open-source software Meshlab was used for the alignment and for the filling of 
gaps and removing noise. The four 3D models resulting from the alignment of the sets of five parts, showed approximately $7 \mathrm{M}$ vertices.

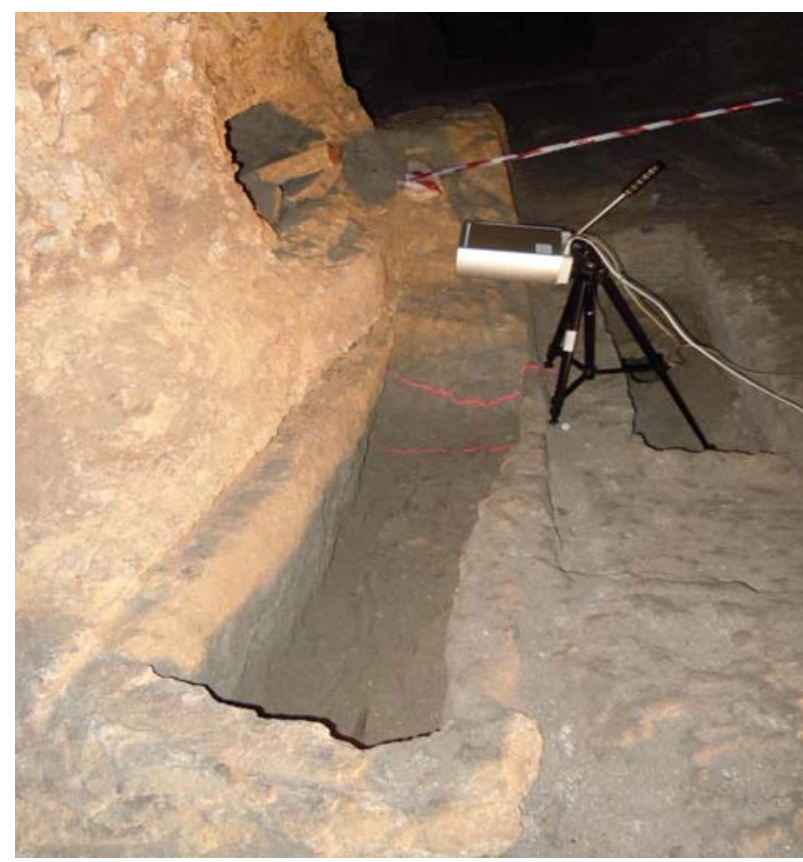

Figure 8: Acquisition via triangulation laser scanner of skeletal remains of tomb 2174

\subsection{The 3D digital documentation of the architectural disiecta membra from old excavations}

Due to a decision taken by the Pontifical Commission for Sacred Archaeology, which supervises every scientific enterprise undertaken in the catacombs of St. Lucy, a number of architectural elements that were discovered during the excavation of the 50 s in nearly every room of the oratory $\mathrm{C}$, were not moved to the storeroom but left near their places of discovery. Preliminarily discussed in the scientific literature, they were never properly catalogued and documented. Twenty-two pieces (SL01SL22), mostly related to the later phase of use of the oratory, including portions of parapets, columns, capitals, inscriptions and stone vessels, were collected and studied and their find-spots recorded (Fig. 9).

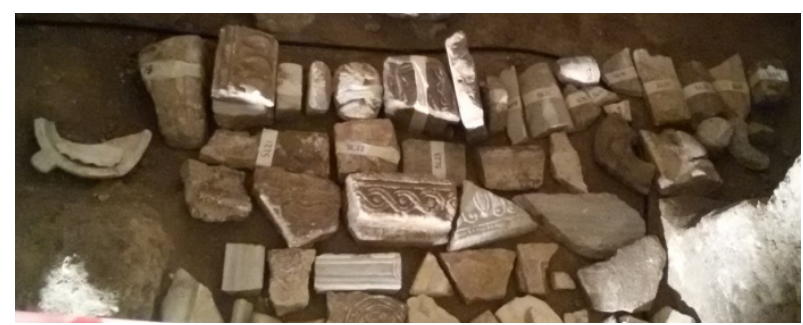

Figure 9: Architectural elements from old excavations at Oratory C.

The tight working schedule led us to carry out the 3D documentation of the pieces via Image Based 3D Modelling (Olson and Placchetti 2015) in order to speed up the digitization process. The artefacts were set on a wooden turntable and photographed with a Nikon D3300 with 24.2 MP, producing a data-set of 40-70 pictures for every object (Fig. 10). Subsequently, the processing occurred via Agisoft Photoscan on the workstation of the Arcadia Virtual Archaeology Lab (Fig. 11). The semiautomatic reconstruction process took intermittently three weeks due to the high number of visual sources (slightly less than 1.500 high quality pictures). The final results represented by the high quality $3 D$ models of the disiecta membra surpass every other alternative documentation method (Fig. 12).

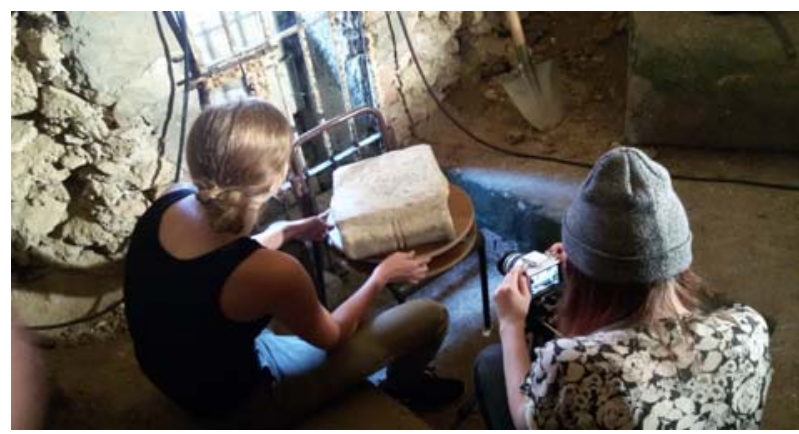

Figure 10: Arcadia University students acquiring the data set of pictures.

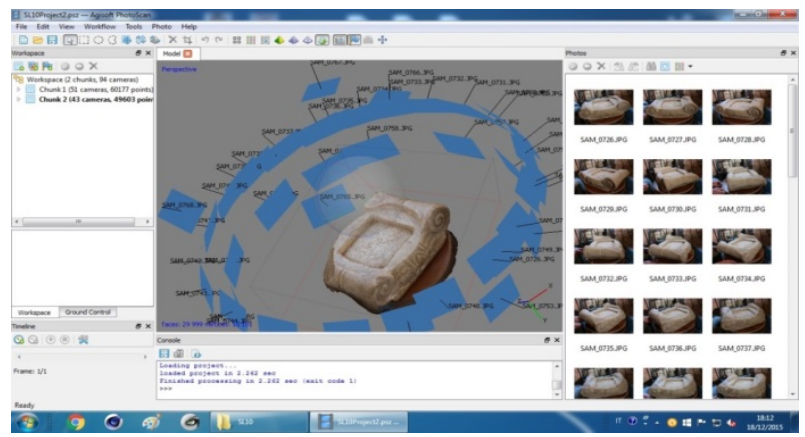

Figure 11: Processing of the 3D model of piece SL10 via Image Based 3D Modeling technique with a data set of 90 pictures.
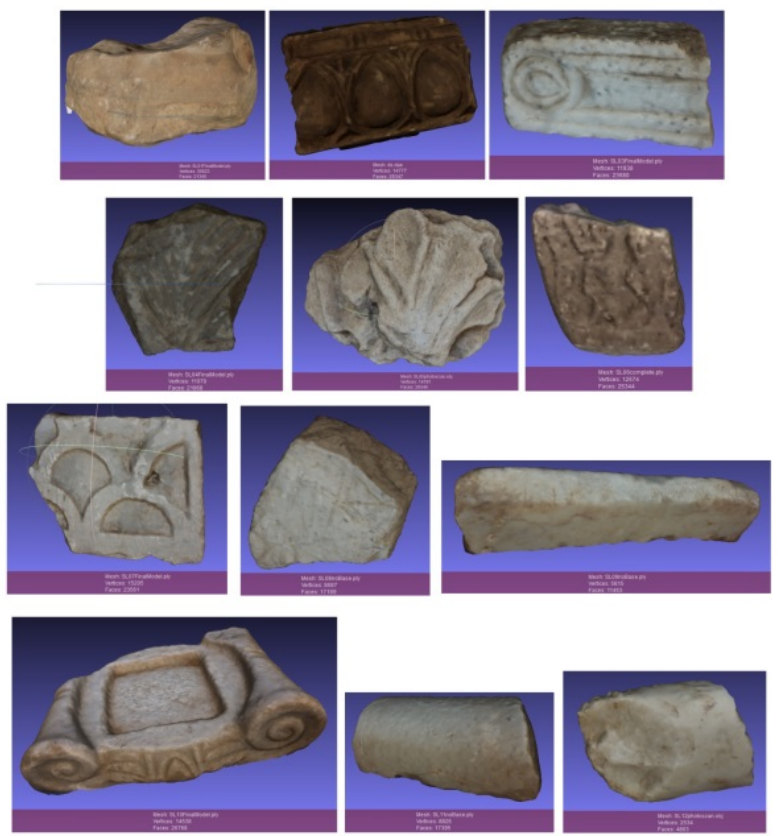

Figure 12: 3D models of architectural elements SL01-SL12 from old excavations at Oratory C, Region C. 


\subsection{The 3D digital documentation of the trench of tombs 2006-2009 in Room L}

The complex stratigraphic deposit represented by the three tombs 2006-2009, set in the south-eastern side of Room L, was a perfect case-study for the application of $3 \mathrm{D}$ digital imaging to record excavation data. In fact, the series of architectural transformations that the three tombs underwent during several phases of reuse was particular. It was also important to document as best as possible the relationship between the three tombs and the others nearby. The data was acquired using an infrared light structured portable scanner (Occipital Structure) to create an untextured high quality $3 \mathrm{D}$ model to represent in detail stratigraphic relations (Figs. 13, 14).

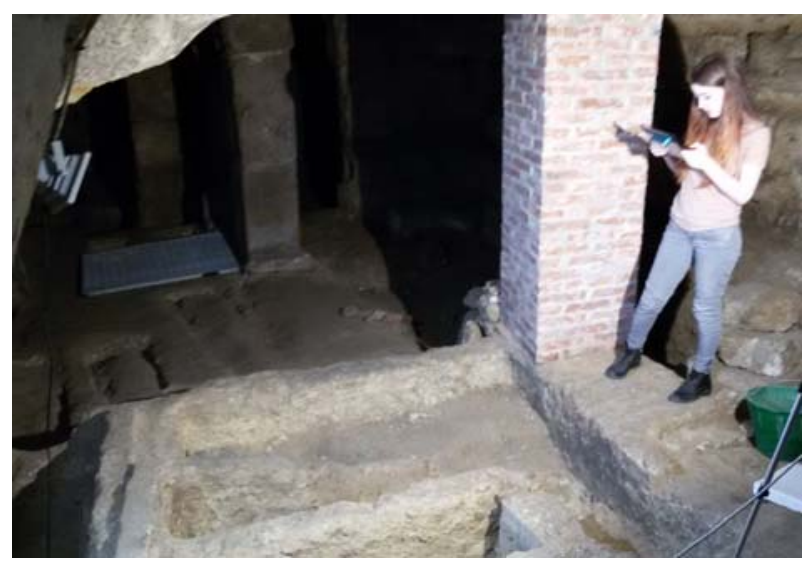

Figure 13: Room E, Oratory C: data set acquisition via a portable infrared light structured 3D scanner (Occipital Structure) of the area of tombs 2006-2009.

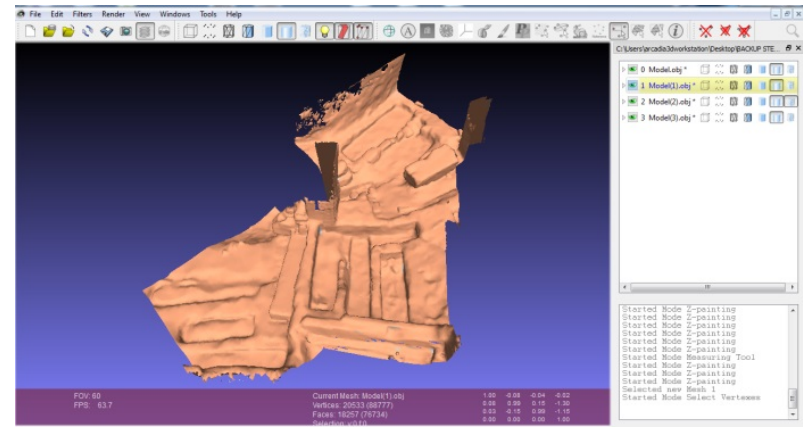

Figure 14: Room E, Oratory C: 3D models of the tombs 20062009 and of the nearby clusters of burials.

\section{Pagan Shrine}

The so called 'Pagan Shrine' in the south-western corner of Regio $C$ is certainly the most important structure predating the foundation of the communal cemetery. With its complex of frescoes with mundane themes and pagan deities, dated between the 1st century $B C$ and $1 \mathrm{st}$ century $A D$, this hypogeal Pagan Shrine, later encompassed in the catacombs without any damage caused to the paintings, still has a central place in the academic dispute.

Located in the less accessible and rather dangerous part of the Region $\mathrm{C}$, it has always been closed to the public and accessible just to a few scholars in the past decades. Seeing as all the necessary equipment was being deployed in Region $C$ for the digital recording of excavation data, it was decided to attempt the acquisition of the complex in order to produce a virtual replica of the Pagan Shrine for the first time.

Due to dimensions of the chamber, the technique of Image Based 3D Modelling was applied, using coded targets set on the walls in order to create a reference system for the alignment phase. A data-set of 310 pictures was produced using a Nikon D3300 with 24.2 $\mathrm{MP}$, covering every spot of the surfaces of the chamber (Fig. 15).

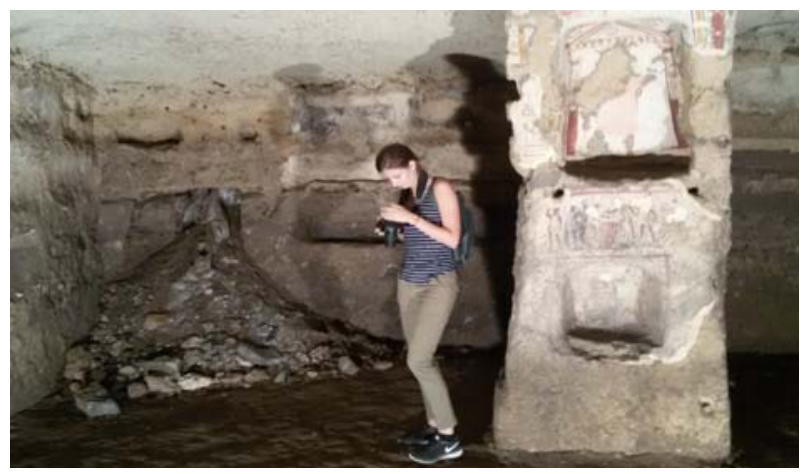

Figure 15: Data set acquisition at the Pagan Shrine.

Subsequently, the processing occurred via Agisoft Photoscan on the workstation of the Arcadia Virtual Archaeology Lab (Fig. 16). The semi-automatic reconstruction process took 27 hours and produced a flawless high quality 3D model of the Pagan Shrine. The model was later exported in the Game Engine of Blender in order to create an interface for the interactive model (Oikarinen 2016) (Fig. 17). In this way, it is now possible for everyone to explore the Pagan Shrine virtually.

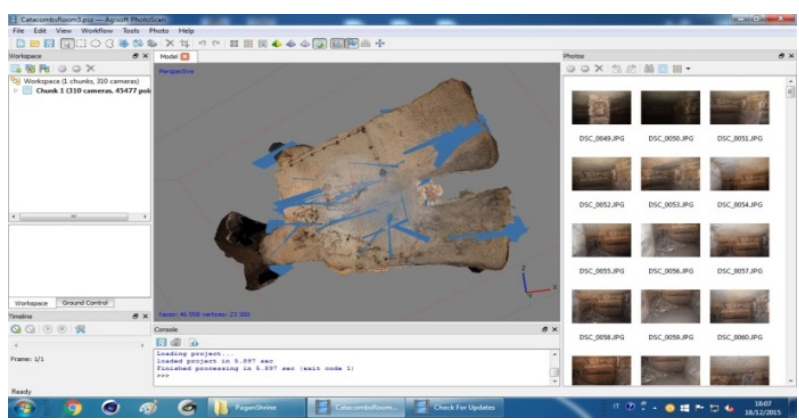

Figure 16: Data processing of the 3D model of the Pagan Shrine via Image Based 3D Modeling technique with a data set of 310 pictures.

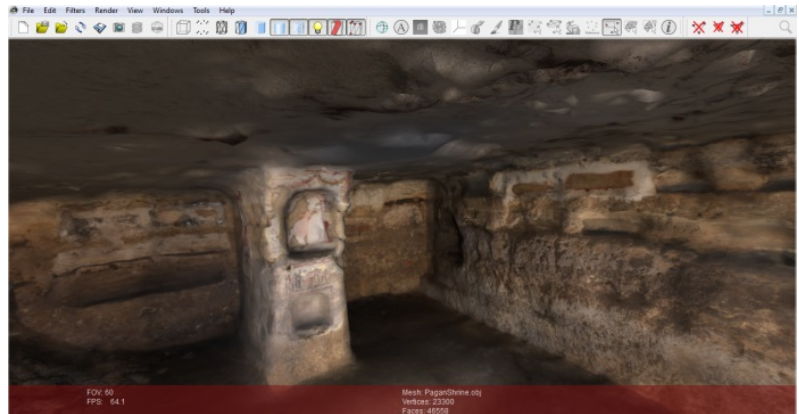

Figure 17: High quality interactive 3D model of the Pagan Shrine. 


\section{Crypt VI}

The hardest but also the most rewarding task regarding the application of 3D digital imaging of the entire excavation campaign was the 3D scanning of the entirety of Crypt VI, a complex about which the available graphic documentation is outdated and incomplete (Fig. 18). The operation was meticulously prepared, taking into consideration the complex plan of the crypt, with three main corridors (B1, B2, B3) and two lower levels (east and west) partly flooded with water coming from an underground spring. The data acquisition project included 16 points of scanning to cover every part of the crypt and a number of markers in strategic spots to be used to link the digital portions.

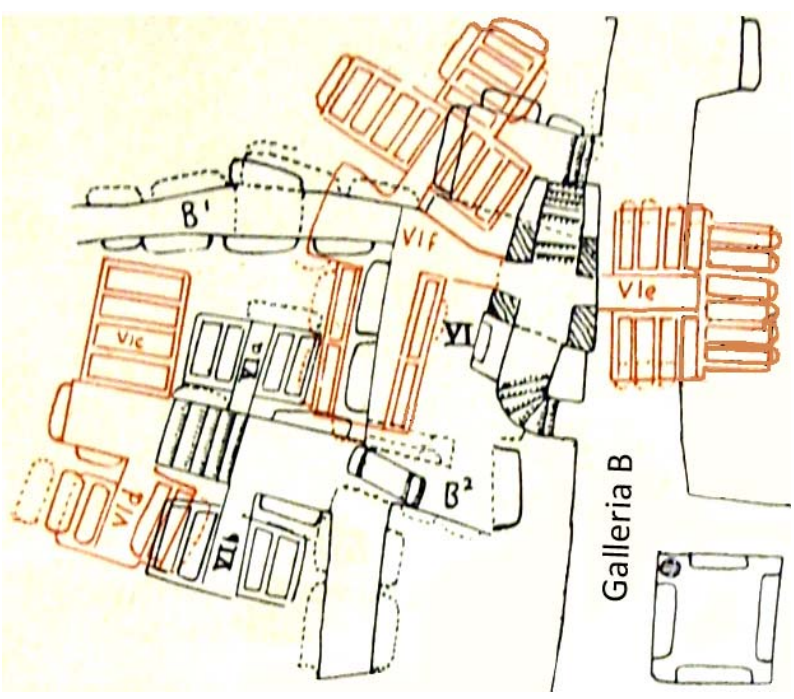

Figure 18: Plan of the Crypy VI.

Considering the unstable power system, the presence of water, the poor light conditions and the very real chance for the digital equipment to be damaged, it was decided to use a low-cost infrared light structured portable 3D scanner (Microsoft Kinect) connected with one of the workstations of the Arcadia Virtual Archaeology Laboratory. Well aware of the limits that the Kinect has as a 3D scanner, especially in consideration of the structural complexity of Crypt $\mathrm{VI}$, it was decided nonetheless to attempt the scan of it. In fact, the educative importance of the task, in this case, would have been higher than the accuracy of the outcome.

The 3D scanning that took place alternated with the excavation works throughout the 4 weeks of excavations. 127 coded targets were applied on the wall of Crypt VI in order to facilitate the subsequent alignment of all the portions.

The huge mass of data acquired in the field took a long time to be processed but ultimately a point cloud 3D model, counting 8.9991.369 faces and resulting from the combination of the 16 scans, was obtained (Fig. 19).

As the 3D model includes both floors and ceilings, it needs to be elaborated in order to get section views and plans and this part of the processing work is still ongoing. The complexity of the $3 \mathrm{D}$ model is such that any further elaboration has to be carried out on the untextured model (Fig. 20). The scans included Corridor B1, never documented before, and the western flooded area, in which it was possible to capture the floor surface for the first time thanks to a particular low level of water (Fig. 21). Unfortunately it was not possible to acquire the two chambers of the eastern flooded area, containing the sarcophagi and accessible through a staircase from a monumental landing, as the level of the water was consistently at $0,50-0,60 \mathrm{~cm}$ of height and covering them. However the structure and complex plan of the landing itself was documented in detail and it is currently under processing. With all its limits, coming from the use of the Microsoft Kinect as scanner, the outcome represents the best documentation of Crypt VI available so far and its 3D model can be certainly used to plan the overall 3D scanning of the complex with a time-of-flight $3 d$ scanner which has been already scheduled.

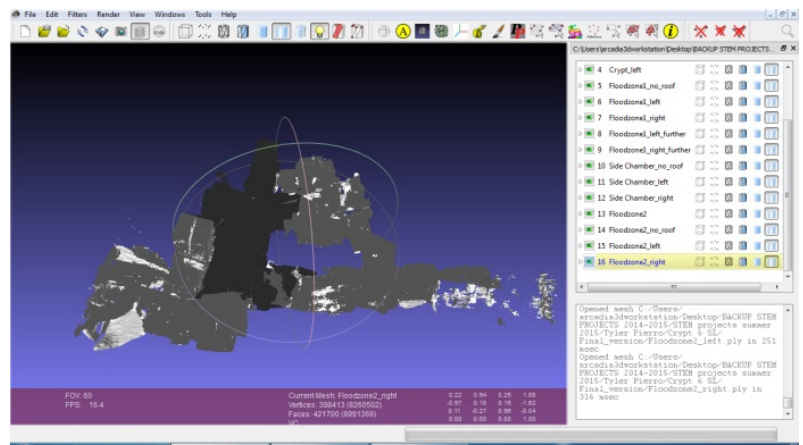

Figure 19: General point cloud 3D model of the entire complex of Crypt $\mathrm{VI}$ (upper and lower levels) obtained by the combination of 16 scans (8.991.369 faces).

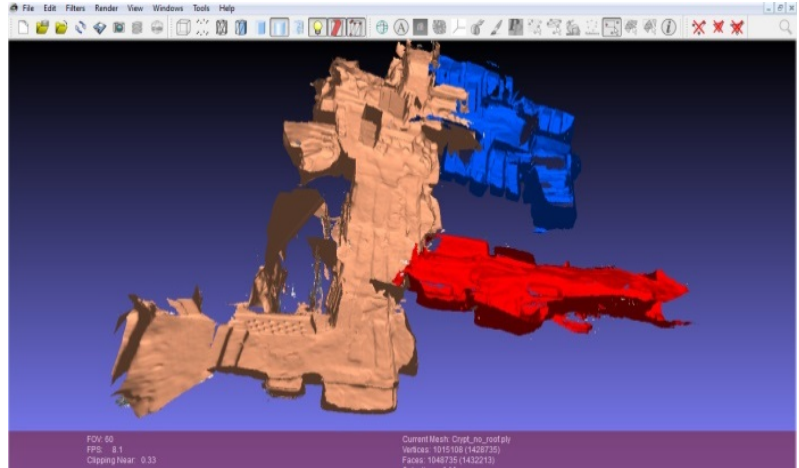

Figure 20: Untextured section view of the 3D model of Crypt $\mathrm{VI}$ (in pink corridor B2, in blue corridor B3 and related lower level, in red corridor B1).

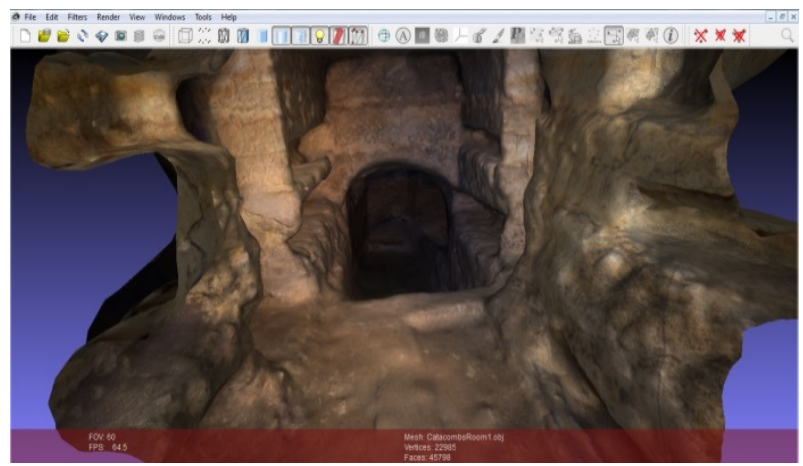

Figure 21: Textured 3D model of the corridor $\mathrm{B} 3$ and the staircase to the west lower level. 


\section{Final remarks}

This contribution has set out the results of the application of an ensemble of 3D digital imaging techniques to record the excavation data of 2013-2015 explorations in the catacombs of St. Lucy at Siracusa. Although the applications of such techniques is quite customary, in this specific case study the production of 3D models of areas of the complex usually not accessible to public has contributed to its popularization (Ferdani and Bianchi 2016).
The 3D data will certainly be helpful for the postexcavation studies, considering that the catacombs are hardly accessible outside of the fieldwork periods. But the most important result achieved is represented by the full involvement of undergraduate students in a firsthand experience in digital archaeology. Students have, in fact, learned new, innovative and affordable methods to record and process excavation data. This alternative approach to the subject of their study - the catacombs combined with the immersive experience that the excavation itself grants has provided important learning outcomes (Healey and Jenkins 2009).

\section{References}

CIGNONI, P. CALLIERI, M., CORSINI, M., DELLEPIANE, M., GANOVELLI, F. and RANZUGLIA, G., 2008. MeshLab: an Open-Source Mesh Processing Tool, in V. SCARANO, R. DE CHIARA, U. ERRA, eds, Proceedings of Eurographics Italian Chapter Conference, pp. 1-8.

DELLI PONTI, F., GUIDAZZOLI, A., LIGUORI, M.C. and IMBODEN, S., 2011. A Blender Open Pipeline for a 3D Animated Historical Short Film, in Proceedings of the 12th International Symposium on Virtual Reality, Archaeology and Cultural Heritage, VAST 2011, pp. 81-90.

ECONOMOU, M., 2015. Heritage in the Digital Age. In: W. LOGAN, M. N. CRAITH AND U. KOCKEL, eds, A Companion to Heritage Studies. New York: John Wiley \& Sons 2015, pp. 215-228.

FERDANI, D. and BIANCHI, G., 2016. Recording, preserving and interpreting a Medieval Archaeological Site by Integrating Different 3D tehcnologies. In In S. CAMPANA, R: SCOPIGNO, G. CARPENTIERO, M. CIRILLO, eds, CAA 2015. Proceedings of the 43rd Annual Conference on Computer Applications and Quantitive Methods in Archaeology, Oxford: Archaeopress, pp. 213-225.

HEALEY, M. and JENKINS, A., 2009. Developing undergraduate research and inquiry. The Higher Education Academy 2009, pp. 1-151.

HUGGET, J., 2013. Disciplinary Issues: Challenging the Research and Practice of Computer Applications in Archaeology. In: E. GRAEME, T. SLY, A. CHRYSANTHI, P. MURRIETA-FLORES, C. PAPADOPOULOS, I. ROMANOWSKA AND D. WHEATLEY, eds, Archaeology in the Digital Era, Papers from the 40th Annual Conference of Computer Applications and Quantitative Methods in Archaeology (CAA), Southampton, 26-29 March 2012. Amsterdam: Amsterdam University Press.

OIKARINEN, T., 2016. Utilisation of Game Engine for Archaeological Visualization. In S. CAMPANA, R: SCOPIGNO, G. CARPENTIERO, M. CIRILLO, eds, CAA 2015. Proceedings of the 43rd Annual Conference on Computer Applications and Quantitive Methods in Archaeology, Oxford: Archaeopress, pp. 27-34.

OLSON, B.R. and PLACCHETTI, R.A., 2015. A Discussion of the Analytical Benefits of Image Based Modeling in Archaeology. In: B. R. OLSON, W. R. CARAHER, eds, 3D Imagining in Mediterranean Archaeology. Fargo: The Digital Press at The University of North Dakota 2015, pp. 17-26.

SGARLATA, M. and SALVO, G., 2006. La Catacomba di Santa Lucia e l'Oratorio dei Quaranta Martiri. Siracusa: Pontificia Commissione di Archeologia Sacra.

STANCO, F. and TANASI, D., 2011. Experiencing the Past. Computer Graphics in Archaeology. In: F. STANCO, S. BATTIATO, G. GALLO, eds, Digital Imaging for Cultural Heritage: Analysis, Restoration and Reconstruction of Ancient Artifacts. Boca Raton: CRC Press, pp. 1-37.

SGARLATA, M., 2007. La catacomba di S. Lucia a Siracusa: origini e trasformazioni. In: R. M. BONACASA CARRA, E. VITALE, eds, La cristianizzazione in Italia tra Tardoantico e Altomedioevo. Atti del IX Congresso Nazionale di Archeologia Cristiana. Agrigento, 20-25 novembre 2004, Palermo: Carlo Saladino Editore pp. 1565-1588.

ZIMMERMANN, N. and EßER G., 2008. Showing the invisible - documentation and research on the Roman Domitilla catacomb, based on image laser scanning and 3D modelling. In: A. POSLUSCHNY, K. LAMBERS, I. HERZOG, eds, Layers of Perception. Proceedings of the 35th International Conference on Computer Applications and Quantitative Methods in Archaeology (CAA), Berlin, 2-6. April 2007. Bonn: Koll. Vor- u. Frühgesch, pp. 58-64. 